\section{THE METAPHORICAL DIMENSION OF LGBTQ INFORMATION: Challenges for its subject representation}

\author{
José Augusto Chaves Guimarães* \\ Francisco Arrais Nascimento ${ }^{* *}$ \\ Fabio Assis Pinho
}

keywords: Knowledge Organization. Representation. LGBTQ.

\begin{abstract}
Having language as a practice of signification, permeating every system of representation that subsidizes forms of resistance and escape lines, one has the possibility of visualizing the processes by which the identities of the subjects are constructed, leading us to think The performativity. It is proposed to enter the sphere of the gender discussions, under the gore of the discourse, being situated theoretically-methodologically in a discursive-deconstructionist perspective, resorting to Foucaultian-based poststructuralist studies, in addition to the relation with queer theorizations, in the form of documentary research of an exploratory nature based on 25 minutes published between 2006 and 2013 by two NonGovernmental Organizations - NGOs in the Cariri Cearense region of Northeast Brazil. The objective was to understand the contribution of the Knowledge Organization - KO in the representation of the discursive practices of the LGBTQ universe. Guiding the research under the contributions of Albrechtsen and Hjørland (1995), Hjørland (1997, 1999, 2002), Tennis (2012) and Guimarães (2008) in the scope of Information Science. In addition to the contributions of the work of Foucault and studies of representation and linguistics. Finally, the results revealed that the themes of the LGBTQ discursive community constitute a complex and highly metaphorical universe, much owed to the marginal conditions that refer to the history of this area, with strong prejudices about sexual practices. This situation demands a greater ethical concern with the indexation and classification systems, so that they can represent all the thematic wealth of the domain, from the documents of the subjects and the communities able to lead the understanding and search of identities that surround them.
\end{abstract}

\footnotetext{
* Doutor em Ciências da Comunicação pela Universidade de São Paulo, Brasil. Professor Titular da Universidade Estadual Paulista Júlio de Mesquita Filho, Brasil. Docente permanente do Programa de Pós-Graduação da Universidade Estadual Paulista Júlio de Mesquita FiIho, Brasil. Bolsista de Produtividade do CNPq.

E-mail: guima@marilia.unesp.br.

** Mestre em Ciência da Informação pela Universidade Federal de Pernambuco, Brasil. Professor da Universidade Estadual Vale do Acaraú, Brasil. Doutorando no Programa de Pós-Graduação da Universidade Estadual Paulista Júlio de Mesquita Filho, Brasil.

E-mail: francisco.arrais.nascimento@ gmail.com.

**** Doutor em Ciência da Informação pela Universidade Estadual Paulista Júlio de Mesquita Filho, Brasil. Professor Adjunto da Universidade Federal de Pernambuco, Brasil. Docente permanente do Programa de Pós-Graduação da Universidade Federal de Pernambuco, Brasil.

E-mail: fabiopinho@ufpe.br.
}

\section{INTRODUCTION}

I $\mathrm{n}$ order to get into the universe and research purposes, it is necessary to rethink the human cognitive and semantic processes that make it an essentially social being - the language. For (SHERA, 1977, p.10):
A linguagem do cérebro é metafórica, - que é a essência da analogia: e em verdade, o que faz do homem um ser singular, é sua capacidade altamente desenvolvida de conceituar a experiência e comunicar as conceituações através de representação simbólica. Uma necessidade constante do cérebro por algo de que ele possa se alimentar, pode ser vista como um impulso humano básico, e o poder de comunicar se torna 
não uma feliz e fortuita invenção, mas uma necessidade essencial e inevitável à sobrevivência humana. "No começo era o verbo" ("In the beginning was the word") - na verdade sem o "verbo" dificilmente teríamos um princípio.

Language as "o uso da palavra articulada (na voz) ou escrita como meio de expressão e de comunicação entre pessoas, a forma de expressão pela linguagem que é própria dum indivíduo, grupo, classe." (FERREIRA, 2001). Mengarda (2001, p.43) complements this reasoning stating that:

\begin{abstract}
A língua é um organismo vivo e se transforma com o uso. São os falantes que provocam as mudanças na língua. A escrita registra as mudanças e é através dela que podemos verificar suas transformações ao longo do tempo em todas as línguas humanas.
\end{abstract}

According to (PRETI, 2000, p.12),

[...] a língua é o suporte de uma dinâmica social que compreende não só as relações diárias entre os membros da comunidade como também uma atividade intelectual que vai desde - fluxo informativo dos meios de comunicação de massa até a vida cultural, científica ou literária.

Therefore, having language as a practice of signification, permeating any and all system of representation that subsidizes forms of resistance and escape lines, one has the possibility of visualizing the processes by which the identity of the subjects is constructed, taking us to think in performativity. In this way, it can be seen that, just like the identities, gender and even sexuality are normalized through the mechanisms and policies of coercion of the body, thus generating a whole range of subjects that make use of "performance" as a form of resistance or even protection against the sanctions imposed by the current norm. It is important to emphasize that the "performance" does not always occur consciously; When speaks of certain concepts, the devices of social coercion and biopolitics of bodies and their production are so dissolved in society and end up being internalized by the subjects, who do not perceive the extent of their action on their body. The principles governing the approach adopted in this proposal are the same as those adopted by (SOARES, 2012, p.7-8):
1) Subjects are constituted by symbolic and historical components. It is not, therefore, a question of individuals understood as beings who have a particular existence in the world. The subject, in this perspective, is not an individualized human being, but must be considered as a social being. It must be understood from a collective space. For a Speech Analyst - SA, the historical and symbolic not separate, but maintains a symbiotic relationship in the construction of being, and consequently the speech.

2) There is no discourse without subject, or subject without ideology. Ideology for a SA is not dissimulation or concealment of truth. Their functioning makes the senses seems obvious when in reality they are constituted of the process in which the subject comes into play, the conditions of production and their inscription in different discursive formations, (ORLANDI, 2010).

3) Subject and meaning are constituted at the same time. In making sense, the subject is signifying itself.

4) So that the words make sense it is necessary that they already make sense (ORLANDI, 1996), are inscribed in history, because each time has its way of naming and interpreting the world. This is a complex memory process. There sayings already said and forgotten that are in us and that when we hear a word, a proposition, it appears as making a certain sense. Discursive memory is made up of forgetfulness. We forget when the senses are formed in us; They appear to us as evident.

5) We live in a society structured by division (class, race, sexuality) and power relations. Therefore, the senses are not the same for all, even though they seem to be.

Among the elements that emerge from social analysis, sexuality has a privileged role. In this way, from an extended perspective, it assumes its plurality and here mentioned as sexualities, in this case homosexualities, in an attempt to contemplate the multiplicity of such experiences. This makes us realize that this is a topic widely discussed today, given the emerging 
visibility, coming from social movements. However, what was built around and about the homosexualities in the nineteenth and twentieth centuries and which endures in modern times still has a strong pathological perspective that permeates relationships, anchored in the biomedical vision that has grounded the discourses since the nineteenth century.

In this way we can understand that lesbians, gays, transvestites, transsexuals, intersexuals, crossdressers - CD, drag queens, drag kings, men who have sex with men - MSM, g0ys, highsexuals among other identity/sexual manifestations cause the scene and provoke discussions turned to an open perspective to rethinking the subjects positions in the social context. Although the socially applied concept of deviant, perverse, nefarious, abject, inverted, and sodomite has moved during history and culture in Brazil, it can still be observed that homosexualities has occupied a prominent place within such conceptualizations throughout history and evolution of scientific knowledge. It is understood, therefore, that the body as the identities, are constructed from the discourses. Consequently, a discursively constructed body can not be unlinked from the linguistic acts that name and constitute them.

According to the interpretation of the work of Judith Butler by (SALIH, 2012, p.232):

\begin{abstract}
$\mathrm{Na}$ medida em que a nomeação da "menina" é transitiva, isto é, em ela inicia o processo pelo qual é imposto um certo "tornar-se menina", o termo ou, mais precisamente, o seu poder simbólico, determina a formação de uma feminilidade corporalmente encenada que nunca preenche plenamente a norma. Essa é, entretanto, uma "menina" que está obrigada a "citar" a norma para se qualificar e se manter como um sujeito viável. A feminilidade não é, então, a consequência de uma escolha, mas a citação forçada de uma norma, cuja complexa historicidade é indissociável de relações de disciplina, regulação, punição.
\end{abstract}

It can be perceived that, just like the identities, gender and even sexuality itself is normalized through the mechanisms and policies of coercion of the body, generating with it a whole range of subjects that make use of "performance" as a form of Resistance or even protection against the sanctions imposed by the current norm. It is important to emphasize that performance does not always occur consciously; When we speak of certain concepts, the devices of social coercion and biopolitics of bodies and their production are so dissolved in society and end up being internalized by the subjects, who do not perceive the extent of their action on their body.

Sexuality begins to be perceived from the emergence of identities that occupy roles that emphasize sexual aspects, being framed within the deviation, outside the hegemonic norm of heterosexuality. So, according to (WOODWARD, 2000, p.8) "As identidades adquirem sentido por meio da linguagem e dos sistemas simbólicos pelos quais elas são representadas [...] Existe uma associação entre a identidade da pessoa e as coisas que ela usa". For (SAUSSURE, 1978) the language (speech) is external to individuals, so it is a social fact. Thereby, the view of language as a inseparable phenomenon from its context of sociocultural production is also shared by (BAKHTIN, 1997; 2004).

The initiatives to organize information for LGBTQ users consider the terminology used by them so the works are properly classified and indexed in a way that reflects their idiosyncratic universe, as a community that produces and consumes information.

The terminological studies for the LGBTQ domain have considered the literary warrant, cultural warrant, and use warrant (BEGHTOL, 1986; 2002; 2005), (BARITÉ; FERNÁNDEZMOLINA; GUIMARÃES \& MORAES, 2010), respecting a transcultural ethics of mediation (GARCÍA GUTIÉRREZ, 2002), and imposing limits to the "power to name" of the indexer (OLSON, 2002) regarding their possible prejudices and antipathies (BERMAN, 1993).

The LGBTQ vocabulary constitutes a specialty language that includes rich figures of speech and reveals a multiple dimension, to the extent that allows, on the one hand, to limit the understanding of this vocabulary to the speakers of that domain, and, on the other hand, to reveal all the richness of the images that populate the LGBTQ universe (PINHO \& GUIMARÃES, 2012).

Therefore, this research is concentrated geographically in the Cariri region, in the south of Ceará State in Northeastern Brazil, which was named on the occasion of the Indian tribes Kariri. 
The region in question had its growth in both population and urban driven by the miraculous phenomenon where a host transformed into blood in the mouth of a Catholic nun who was called Maria de Araújo. This fact resulted in migratory cycles of pilgrims, popularly called of 'romeiros', visiting the area at certain times of the year recognizing it as a holy place. The cultural scene of Cariri became rich in a broad aspect, especially the celebration of the various practices of a religious nature.

Therefore, the culture in various aspects has always been guided by the standard of the unique identity giving space only to cultural products of religious or traditional heteronormative nature. Especially the cultural side of deviant character not stood out or was simply marginalized, forgotten or excluded from the historical construction of the analyzed region. However, this does not mean that this minority does not exist in the region.

Because of the lack of democratic space and the right of free homosexual expression, the meetings of this group of individuals presented themselves in places of space. However, currently the homosexual culture has greater disclosure and its audience is consolidated to ensure their rights, generate income and a whole cultural and creative economy, in addition to democratize space giving voice to minorities by LGBTQ activists working for homosexual rights and democratic space.

In this sense, this research is focused on the terminological aspects of male homosexuality, a domain of knowledge that materializes through terminology. So, it takes into account the Domain Analysis - DA.

The concept of DA was first used by Neighbors in 1980 in the area of Computer Science, aiming to identify the elements (operations, objects and relationships) that experts of a given domain consider as significant for their activities (KERR, 2003). In Information Science, DA has been studied for two decades, as highlighted by (SMIRAGLIA, 2015, p. 1):

\footnotetext{
Toward the end of the twentieth century, the $\mathrm{KO}$ community turned to a postmodern view of knowledge (Mai, 1994, Smiraglia, 2012) in which domain-centric points of view and interoperability among them replaced the search for global (universal, catholic,
}

unitary, etc.) systems. In this new reality domain analysis, or the study of the knowledge bases of specific, definable contexts, has become a core paradigm within the knowledge organization community.

In this context, we highlight the seminal text of (HJØRLAND; ALBRECHTSEN 1995) which was later delved deeper by (MOYAANEGÓN; HERRERO-SOLANA, 2001), (HJØRLAND, 2002; 2004), (TENNIS, 2003), (MAI, 2009), (SMIRAGLIA, 2011, 2012), (GUIMARÃES, 2015) and (GUIMARÃES; TOGNOLI, 2015) among others.

As pointed out by (HJØRLAND \& ALBRECHTSEN, 1995) and (HJØRLAND, 2002), Domain Analysis - DA, especialy in the Informaiton Science field, deals with the subject matter of understanding of Information Science - the recorded and socialized information through the analysis of fields of knowledge as a whole or discursive communities, especially in addressing the terminological studies. It also takes into account the Communicative Terminology Theory - TCT (CABRÉ, 2005), since the terminology is dedicated to the observation of the behavior of the terms and their relation to the scientific knowledge and thus, points theoretical elements and practical principles capable of guiding the search, selection and ordering terms of that domain knowledge. Moreover, the specific analysis in relation to the male homosexual was not encompass other related matters as they would result in excessive elongation field, and therefore, would damage the analysis by the lack of specificity.

Then, the general aim of this research was to analyze and categorize the terms of a specific homosexual community of Cariri Cearense region, in Brazil, through the minutes of nongovernmental organizations - NGOs.

\section{CONTEXTUALIZATION OF RESEARCH}

The Cariri Cearense presents a great militancy of the LGBTQ movement such as the non-governmental organizations - NGOs, in the fight against the AIDS syndrome epidemic, political activism, the very cultural heritage represented by the audiovisual production, 
creative services, new media, design, publishing, print media (twine, brochures, booklets) and visual arts (painting, sculpture, photography, crafts).

In this sense, the minutes of two NGOs Grupo de Apoio a Livre Orientação Sexual Cariri - GALOSC and the Associação de Apoio, Defesa e Cidadania dos Homossexuais - AADECHO - were - analyzed during the period between 2006 to 2013. This period was marked by strong political and cultural pressures in the global context that echoed in the local context and this political and cultural environment led to higher claims for the recognition of citizenship and rights, given the new national opening scene to LGBTQ issues and so a new agenda in the discussion where it sees further discussions on topics that emerge from the records of the minutes of the NGO. Among them may be noted that in addition to the AIDS theme, prevention and violence, the record reveals a greater role in the struggle for human rights, being noticeable in the speeches support for equal marriage and the new opening that is observed at the national level.

For this study were initially carried out the identification and chronological organization of the minutes, in order to facilitate the search and groupings of information, from the frequency, the fact registered and the corresponding period. Thus, it proceeded to the analysis of documents from which emerged relevant themes to the study by their frequency and occurrence. It may be related to the context in which they were produced because of the strong link of the themes with the socio-political, cultural and economic contexts in which they were immersed. This analysis was performed from the reading of the minutes, macrostructures identification and extraction of concepts, in conjunction with the relevant theoretical frameworks.

This research is theoretically supported in the fundamentals of domain analysis in Information Science, which can be configured as a social paradigm conceived by area, with focus on a functionalist approach that aims to understand the implicit and explicit functions of information and finally communication (HJØRLAND; ALBRECHTSEN, 1995).

Thus, and basing on (HJØRLAND; ALBRECHTSEN, 1995), (HJØRLAND, 1997; 2002), and (TENNIS, 2003; 2012) domain analysis theoretical approaches, and in order to perform a qualitative, historical and functional analysis of the information, this research establishes a cross analysis between two sources: the data from the minutes prepared by LGBTQ NGOs of Cariri and the data provided by the speeches of the activists who work or worked in militancy in that region. Those sources reflect collective fields of knowledge or areas of knowledge concerning their discursive communities. These communities are not autonomous entities, but different social constructions understood by individuals synchronized in thought, language, and knowledge, and constituents of modern society (SMIRAGLIA, 2012).

Then the process of understanding the gay movement in Cariri Cearense region by reconstructing the same under the influence of the organization of knowledge can be allocated in order of field analysis, since in view of the foregoing, it is believed that the Domain Analysis enables this interpretation to identify the context in question and its internal and external relationships.

\section{METHODOLOGY}

This documental and exploratory research was based on 25 minutes published between 2006 and 2013 by two non-governmental organizations - NGOs in the Cariri Cearense region in Northeast Brazil ("Grupo de Apoio a Livre Orientação Sexual do Cariri" - GALOSC and "Associação de Apoio, Defesa e Cidadania dos Homossexuais" - AADECHO). The minutes are usually composed of the following structure: 1) Title; 2) Opening; 3) Identification of the members present; 4) Agenda; 5) Closing.

The methodological procedures for the response to the proposed objective initially followed the steps:

a) Domain analysis as a form of to understand the research extension and its scope;

b) Selection and reading of the minutes;

c) Identification and extraction of metaphorical terms;

d) Categorization of the terms.

Regarding the analysis procedures, the first step is the careful reading and (re)reading of empirical materiality in order to try to grasp the meanings that have not been noticed or not said. 
This phase of continuous readings allows the analyst to find repetitive words and phrases that may represent situations more or less coherent and of similar meaning, metaphors which may involve specific images or words with particular meanings.

\section{ANALYSIS AND DISCUSSION}

The Domain Analysis enabled the following interpretation to identify the context in question and its internal and external relations:

The LGBTQ movement in Cariri Cearense region: this movement started in the late 1990s as a form of resistance to the curtailment of the rights of LGBTQ people of Cariri Cearense region and also as a way to denounce the growing violence of everyday practices applied to this group. The historical and sociopolitical contexts made possible the emergence of supporting institutions and fight for citizenship and LGBTQ rights in Brazil and in the locality analyzed. In 2002 came the first NGO in order to strengthen the struggle and organizing the LGBTQ movement.

Scope and reach: for purposes of this domain analysis, minutes of meetings of NGOs and the speech of the militants that sometime endure the LGBTQ movement in Cariri were used.

Extension: All concepts that can be identified in the minutes, as well as their relations.

After the reading of the minutes and the identification and extraction of terms, the result was in a set of 815 metaphorical terms that allow the definition of three thematic categories:

a) Women's Names: Alice, Ana Cláudia, Angélica, Beth Faria, Bruna, Catarina, Cecília, Débora kerr, Edit, Elizabeth, Elza, Haydée, Irene, Ivone, Jacira, Kátia, Margarete, Marisa, Melissinha, Monalisa, Mônica, Naira, Nefertite, Neusa, Vera, Yvone, Zoraide;

b) Body Parts, usually representing the penis or anus: Anel, Beiça, Benga, Bibita, Biloba, Croquete, Edí, Ekê, Estrovena, Frapê, Furico, Gogóia, Grilinha, Indaca, Kibe, Mala, Muxiba, Necão, Neca, Nicaô, Ocâni, Pacoteira, Pacotão, Picumã, Poposuda, Rabico, Quibe, Rosca, and c) Actions, usually linked to sexual intercourse or personality traits: Aquendar uma nequinha, Assoprar a vela (blow the candle), Bater um bolo (beat the cake), Colar velcro, Dança do rebuceteio, Dar a egípcia, Dar a Elza, Fazer a linha, Metade sereia Metade tubarão (half mermaid, half shark), Morder a fronha (to bite the pillow cover), Quebrar a louça (break the porcelain), Sair do Armário (get out of the closed), Soltar a franga (liberate the chicken). The allusion to the world of cinema, television, social life and the arts, such as the use of names of artists and characters deserves special mention (Alice, Angélica, Barbie, Betty Faria, Deborah Kerr, Greta, Jamanta, Kátia, Monalisa, Nefertite, Nikita, Hebe, Susie, Uma Thurman, Vera Boyola, Wonder woman, Xuxa).

As for the linguistic aspect, we found a strong influence of indigenous languages such as bajubá (Carupé, Cosibotó, Cossibaré, Cosibotó, Cossibaré, Edí, Ekê, Mati, Matim, Ocâni, Mitorô, Nena, Ocó, Odara, Ofofi do ofidã, Olofô, Omivará, Oré, Orum, Oté, Otim, Oxanã, Padê, Picumã, Ramé, Uó, Xaxé, Xepó), French (Bas fond, Cachet, Debut, Frappé, Michet, Pochete, Poupée, Travesti), English (Close, Clubber, Cookie, Dyke, Fashion discontrol, Femaleto-male, Free willy, Friendly, Leather, Lipstick lesbian, Pittboy, Tank panzer, Top, Trash, including literal translations to Portuguese of bear, getting out of the closet, hello, miss thing, and trick). We also observed mixed expressions of English and French (Fashion desnecéssaire, Lesbian chic).

These three categories reflect the metaphorical dimension of the terminology used by the gay community studied through the minutes of its NGO. The figures of speech of this discourse community contribute to the construction of their identity. Their metaphors establish relations between the significance of beads and assist in the building of this group. It is in this community discourse these figures of speech gain meanings and each of these terms is a matter of metaphorical nature. This is the great challenge for the knowledge representation.

\section{CONCLUSIONS}

The results revealed that the themes of the LGBTQ discursive community constitute a 
complex and highly metaphoric universe very much due to the marginal conditions that refer to the history of this area, with strong prejudices regarding the sexual practices. This situation requires a greater ethical concern regarding the indexing and classification systems so they can represent all the thematic richness of the domain, stemming from the documents of the subjects and communities capable to lead the understanding and search for identities that surround them.

At the end of the analysis contained in the documents granted by the institution, one can understand the order of a socio-political, economic and cultural context in which the institution found itself immersed and thus reconstruct a given period of LGBTQ movement of the Cariri Cearense understood between the years 2006-2013 and the entire social construction that made the Movement Gay or LGBTQ activism emerge and consolidate in the region of Cariri Cearense. Such a scenario is marked by movements of domination and resistance which emerge speeches and their own dialect as a way to assert themselves in an exclusive context.

It was observed that the terminology used in that discourse community is permeated by the metaphoric dimension (presence of figures of speech that attach new connotative meanings parallel to an initial denotative). Such figures are sometimes misinterpreted or loaded with pejorative connotations and at that time, the indexer's role is to make the representation so that the user belonging to that culture feel reflected by the system, it is not recommended that professional interpose (or even impose) their ideas or their prejudices.

The challenge of knowledge organization is in need of the terminology of discourse communities are included in indexing languages, covering issues of identity. These aspects will help this minority discursive community in constant representation in artificial languages, allowing an understanding of how it is structured.

\section{A DIMENSÃO METAFÓRICA DA INFORMAÇÃO LGBTQ: Desafios para a representação dos sujeitos}

RESUMO Tendo-se a linguagem enquanto prática de significação, permeando todo e qualquer sistema de representação que subsidia formas de resistência e linhas de fuga, tem-se a possibilidade de visualizar os processos pelos quais as identidades dos sujeitos são construídas, levando-nos a pensar a performatividade. Propõe-se adentrar a esfera das discussões de gênero, sob o viés do discurso, situando-se teórico-metodologicamente em perspectiva discursivo-desconstrucionista, recorrendo aos estudos pós-estruturalistas de base foucaultiana, além da relação com as teorizações queer, sob a forma de pesquisa documental de natureza exploratória baseada em 25 minutas publicadas entre 2006 e 2013 por duas Organizações Não-Governamentais - ONGs na região do Cariri Cearense no Nordeste do Brasil. Objetivou-se, compreender a contribuição da Organização do Conhecimento - OC na representação das práticas discursivas do universo LGBTQ. Norteando a pesquisa sob as contribuições de Albrechetsen e Hjørland (1995), Hjørland (1997, 1999, 2002), Tennis (20I2) e Guimarães (2008) no âmbito da Ciência da Informação. Além das contribuições da obra de Paul-Michel Foucault e dos estudos de representação e linguística. Por fim, Os resultados revelaram que os temas da comunidade discursiva LGBTQ constituem um universo complexo e altamente metafórico, muito devido às condições marginais que se referem à história desta área, com fortes preconceitos em relação às práticas sexuais. Esta situação exige uma maior preocupação ética com os sistemas de indexação e classificação, para que possam representar toda a riqueza temática do domínio, a partir dos documentos dos sujeitos e das comunidades capazes de conduzir a compreensão e busca de identidades que os rodeiam.

Palavras-chave: Organização do Conhecimento. Representação. LGBTQ. 


\section{REFERENCES}

BAKHTIN, Mikhail. Estética da criação verbal. 2 ed. São Paulo: Martins Fontes, 1997.

BAKHTIN, Mikhail. O freudismo. São Paulo: Martins Fontes, 2004

BARITÉ, Mario; FERNÁNDEZ-MOLINA, Juan Carlos; GUIMARÃES, José Augusto Chaves \& MORAES, João Batista Ernesto. Garantia literária: elementos para uma revisão crítica após um século. . Transinformação [online], v. 22, n.2, p.123-138, 2010.

BEGHTOL, C. A proposed ethical warrant for global knowledge representation and organization systems. Journal of Documentation, London, v. 58, n. 5, p. 507-532, 2002.

BEGHTOL, C. Ethical decision-making for knowledge representation and organization systems for global use. Journal of the American Society for Information Science and Technology, New York, v. 56, n. 9, p. 903-912, 2005.

BEGHTOL, C. Universal concepts, cultural warrant, and cultural hospitality. In: LÓPEZHUERTAS, M. J. (Ed.). Challenges in knowledge representation and organization for the $21^{\text {st }}$ century: integration of knowledge across boundaries. Würzburg: ERGON-Verlag, p. 45-49, 2002.

BEGHTOL, Clare. Semantic validity: concepts of warrant in bibliographic classification systems. Library Resources \& Technical Services, v. 30, n. 2, p.109-125, 1986.

BERMAN, S. Prejudice and antipathies: a tract on the LC subject heads concerning people. Jefferson: McFarland \& Company Inc. Publishers, 1993.

CABRÉ, Maria Teresa. La Terminología: representación y comunicación: elementos para una teoría de base comunicativa y otros artículos. Girona: Documenta Universitaria. 2005.

FERREIRA, Aurélio Buarque de Holanda. Miniaurélio século XXI: $O$ minidicionário da língua portuguesa. 5. ed. rev. Ampliada. Rio de Janeiro: Nova Fronteira, 2001.

GARCÍA GUTIÉRREZ, A. Knowledge organization from a "culture of the border": towards a transcultural ethics of mediation. In: LÓPEZ-HUERTAS, M. J. (Ed.). Challenges in knowledge representation and organization for the $21^{\text {st }}$ century: integration of knowledge across boundaries. Würzburg: ERGON-Verlag, p. 516522, 2002.

GUIMARÃES, José Augusto Chaves. Análise de domínio como perspectiva metodológica em organização da informação. Ciência da Informação, v. 43, n. 1, 2014. Disponível em: <http:// basessibi.c3sl.ufpr.br/brapci/ v/a/19492>. Acesso em: 28 Jan. 2017.

GUIMARÃES, José Augusto Chaves; TOGNOLI, Natália Bolfarini. Provenance as a domain analysis approach in archival knowledge organization. Knowledge Organization, Wurzburg: Ergon-verlag, v. 42, n. 8, p. 562-569, 2015.

HJØLAND, Birger. Domain analysis: a sociocognitive orientation for Information Science research. Bulletin of the American Society for Information Science and Technology. v.30, n.3, feb./mar. 2004.

HJØRLAND, Birger. Domain analysis in information science: eleven approaches traditional as well as innovative. Journal of Documentation, London, v. 58, n.4, p. 422-462, 2002.

HJØRLAND, Birger. Information seeking and subject representation: an activity theoretical approach to Information Science. London: Greenwood Press, 1997.

HJØRLAND, Birger; ALBRECHTSEN, Hanne. Toward a new horizon in information science: Domain-analysis. Journal of the American Society for Information Science, v.46, n.6, p.400425, Jul. 1995.

KERR, E. S. Ketib: um processo de representação de informação para textos complexos. Campinas, 2003. Dissertação (Mestrado Profissional 
em Ciência da Computação) - UNICAMP. Disponível em: http:libdigi.unicamo.br/ document $/$ ?code $=$ vtls000311557.

MAI, Jens-Erik. "Socio-Cognitivism (Domain Analysis)". In panel on: "Metatheoretical Snowmen". 73 ${ }^{\text {th }}$ ASIST Annual Meeting, (Vancouver, BC). 2009.

MENGARDA, Elias José. Génese e Evolução dos Dialetos Trentino e Véneto. In. Working Papers em Linguística, UFSC, N.5, p. 42 - 57. 2001.

MOYA-ANEGÓN, F.; HERRERO-SOLANA, V. Análisis de dominio da la revista mexicana de investigación bibliotecológica. Informaión, cultura y sociedad, n.5, p. 10-28, 2001.

OLSON, Hope A. The power to name: locating the limits of subject representation in libraries. Dordrecht: Kluwer Academic Publishers, 2002.

ORLANDI, Eni. (Org.). Discurso e políticas públicas urbanas - A fabricação do consenso. Campinas: Editora RG, 2010.

ORLANDI, Eni. As formas do silêncio. Campinas: Editora Unicamp, 2002.

ORLANDI, Eni. Interpretação: autoria, leitura e feitos do trabalho simbólico. Petrópolis: Vozes, 1996.

PINHO, Fabio Assis; GUIMARÃES, José Augusto Chaves. Male Homosexuality in Brazilian Indexing Languages: Some Ethical Questions. Knowledge Organization. Wurzburg: Ergonverlag, v. 39, n. 5, p. 363-369, 2012.

PRETI, Dino. Sociolingüística: os níveis da fala: um estudo sociolingüístico do diálogo na literatura. 9. ed. São Paulo: EDUSP, 2000. (Campi, 15).

SALIH, Sara. Judith Butler e a teoria queer. Belo Horizonte: Autêntica Editora, 2012.

SAUSSURE, Ferdimand de. Curso de Linguística Geral. Lisboa, 1978.

SHERA, Jesse. Epistemologia social, semântica geral e biblioteconomia. Ciência da Informação, Rio de Janeiro, v.6, n.1, p. 9-12, 1977.
SMIRAGLIA, Richard P. Domain coherence within Knowledge Organization: people, interacting theoretically, across geopolitical and boundaries. In: MCKENZIE, P.; JOHNSON, K.; STEVENS, S. (ed.). Exploring interactions of people, places and information, Proceedings of the $39^{\text {th }}$ Annual CAIS/ACSI Conference, University of New Brunswick, Canada, June 2-4, 2011. 6p. http://www.cais-acsi.ca/conferences. htm.

SMIRAGLIA, Richard P. Epistemology of domain analysis. In Cultural frames of knowledge. Würzburg: Ergon-Verlag, p. 111-24, 2012.

SOARES, Alexandre Sebastião Ferari. A construção de identidade sexual: travesti, a invenção do feminino. In. EID\&A - Revista Eletrônica de Estudos Integrados em Discurso e Argumentação. Ilhéus, n.2, p.5 -14. Maio 2012.

TENNIS, Joseph T. Two axes of domain analysis. Knowledge Organization, Frankfurt, v.30, n.3/4, p.191-195, 2003.

TENNIS, Joseph. A convenient verisimilitude or oppressive internalization? Characterizing the ethical arguments surrounding hierarchical structures in knowledge organization systems. Knowledge Organization, v. 39, n. 5, p. 394-397, 2012.

WOODWARD, Kathryn. Identidade e diferença: uma introdução teórico e conceitual. In SILVA, Tomaz Tadeu da. Identidade e diferença: a perspectiva dos Estudos Culturais. Petrópolis: Vozes, 2000. 